\title{
Effects of Levetiracetam on Sleep Architecture and Daytime Sleepiness
}

\author{
Orlina Chaneva \\ Department of Neurology, Medical University of Plovdiv, Plovdiv, Bulgaria \\ Corresponding author: Orlina Chaneva, Department of Neurology, Medical University of Plovdiv, 15A Vassil Aprilov Blvd., 4002 Plovdiv, Bulgaria; \\ E-mail: orlina_chaneva@abv.bg; Tel:. +359 883340068
}

Received: 25 Aug 2020 Accepted: 11 Mar 2021 Published: 31 Oct 2021

Citation: Chaneva O. Effects of levetiracetam on sleep architecture and daytime sleepiness. Folia Med (Plovdiv) 2021;63(5):631-6. doi: 10.3897/folmed.63.e57985.

\begin{abstract}
Sleep is a reversible behavioural state of perceptual disengagement from and unresponsiveness to the environment, which is required for neural plasticity and memory consolidation. Sleep disorders are common in patients with epilepsy. The main causes of sleep disturbances are coexisting sleep disorders, impact of seizures and epileptic activity, and the effects of antiepileptic drugs. Sleep and epilepsy have reciprocal effects - on one hand electrical brain activity during sleep is a strong modulator of epileptic activity and on the other epileptic activity during sleep may disrupt sleep architecture. The most common side effects of anticonvulsants include alterations in sleep architecture and variation in the degree of daytime sleepiness. Their effects on sleep and daytime sleepiness are variable and it is often difficult to distinguish whether the improved seizure control and epileptic activity is a direct result of anticonvulsants or associated with improved sleep quality. Levetiracetam is a new generation anticonvulsant used to treat both focal and generalized epilepsy. Its satisfactory safety and tolerability explain its wide usage in the clinical practice and necessitates more profound knowledge on its effects on sleep quality. There have been few reports about its effects on sleep architecture and daytime sleepiness. A short summary of the studies concerning this topic is presented. Main disadvantages of the studies are: the small sample size, comparison of the results obtained in healthy volunteers with patients with epilepsy, short observation duration, variations of dosage, different evaluation modalities and concomitant AED therapy. Future prospective studies on subjective and objective effects of Levetiracetam on sleep architecture and daytime sleepiness are needed to better understand its impact on sleep in order to improve epilepsy patients' quality of life, seizure control and sleep disturbances.
\end{abstract}

\section{Keywords}

daytime sleepiness, epilepsy, levetiracetam, sleep architecture

\section{INTRODUCTION}

Sleep is a reversible behavioural state of perceptual disengagement from and unresponsiveness to the environment. ${ }^{1}$ It consists of rapid eye movement (REM) sleep and non-REM (NREM) sleep. NREM sleep is further divided into stage N1, N2, and N3 sleep based on electroencephalography patterns. ${ }^{2} \mathrm{~N} 3$ is also termed slow-wave sleep (SWS), and comprises stages 3 and 4 of older nomenclature. ${ }^{3}$ In adult humans, sleep consists of about $5 \%$ wake, $5 \% \mathrm{~N} 1$, $50 \% \mathrm{~N} 2,15 \% \mathrm{~N} 3$, and $25 \%$ of REM sleep. ${ }^{2}$ The physiologi- cal function of sleep is controversial and still to be explored. There are metabolic, endocrine, cardiac, respiratory, and almost all other systems changes that occur during sleep. ${ }^{1}$ Among various hypotheses about the primary function of sleep, restorative and cognitive effects have received an upsurge of attention. There is increasing evidence that sleep is required for neural plasticity and memory consolidation. ${ }^{4}$ SWS is important for declarative memory consolidation, whereas REM sleep supports nondeclarative and emotional memory. ${ }^{2}$ 
Patients with epilepsy often suffer from inadequate or ineffective sleep. ${ }^{5,6}$ Sleep disorders are common in these patients. Frequently patients with epilepsy complain of sleep disruption and report daytime sleepiness. ${ }^{5,7,8}$ The main causes of sleep disturbances are coexisting sleep disorders, impact of seizures and epileptic activity, and the effects of antiepileptic drugs (AEDs). ${ }^{9}$ Seizures themselves can disrupt sleep, even when they occur during wakefulness. ${ }^{10}$ Sleep may also be disrupted in the absence of seizures and anticonvulsant therapy, mainly related to the effects of interictal epileptic activity. ${ }^{6}$ Poor sleep quality can cause considerable impairment of daytime functioning and quality of life. ${ }^{11-13}$ On the other hand, inadequate sleep can induce daytime sleepiness and memory dysfunction, which can lead to persistent seizures. ${ }^{12}$

Sleep and epilepsy have reciprocal effects. Electrical brain activity during sleep is a strong modulator of epileptic activity, and vice versa, epileptic activity during sleep may impair the sleep-wake cycle and sleep architecture. ${ }^{14}$ All this can result in sleep deprivation, which in turn may provoke subsequent seizures. ${ }^{15}$ The effects of AEDs on sleep and daytime sleepiness are variable and it is often difficult to distinguish whether the improved seizure control and epileptic activity is a direct result of AEDs or associated with improved sleep quality. The most common side effects of AEDs include alterations in sleep architecture and variation in the degree of daytime sleepiness. ${ }^{16}$ The main difference between older and newer AEDs concerns especially daytime sleepiness, more often associated with conventional traditional AEDs, newer AEDs are reported to be less sleep disruptive., ${ }^{9,15}$ Older generation AEDs typically reduce the percentage of REM sleep and SWS, increase fragmentation, and induce daytime sleepiness. ${ }^{8}$

Levetiracetam (LEV) is a new generation AED, the S-enantiomer of alpha-ethyl-2-oxo-1-pyrrolidine acetamide, used to treat both focal and generalized epilepsy. Its pharmacodynamics appears to be distinct from that of older AEDs and unrelated to voltage-gated sodium channels, gamma-amino-butyric acid or glutamate-mediated synaptic transmission. ${ }^{17} \mathrm{LEV}$ has a specific mechanism of action - it binds to the synaptic vesicle protein SV2A, interfering with the release of the neurotransmitter stored within the vesicle. ${ }^{18}$ The reported adverse effects of LEV associated with sleep are daytime sleepiness (5-40.4\%), insomnia (2-4.8\%). Nightmares and somniloquy are less frequent. ${ }^{19}$

The broad spectrum of LEV and the satisfactory safety and tolerability explain its wide usage in the clinical practice nowadays. This necessitates more profound knowledge on its effects on sleep quality.

There have been few reports about the effects of LEV on sleep architecture and daytime sleepiness. We present a short summary of the studies (in ascending chronological order of publishing) concerning this topic.

\section{RESULTS}

In 2002, Bell et al. published the results of a study on the effects of LEV on objective and subjective sleep parameters in healthy volunteers and patients with focal epilepsy on stable chronic (>1 year) CBZ monotherapy. ${ }^{20}$ The data on the study design and results are presented in Table $\mathbf{1 .}$ Disadvantages of this study are: 1 . The usage of a single dose of $1000 \mathrm{mg}$ LEV resulting in the impossible evaluation of objective sleep parameters because of lacking LEV accumulation; 2 . The difficulty to assess additive effects of CBZ and LEV in the patients' group; 3. The comparison of results in patients with epilepsy and healthy volunteers could not provide information about underlying epilepsy effects on sleep; 4 . The relatively short duration of observation.

In 2005, Bazil et al. published the results of a study, focused on the effects of LEV on sleep using PSG in healthy subjects only. ${ }^{21}$ The data on the study design and results are presented in Table 1. Disadvantages of this study are: 1 . The participation of only healthy subjects excludes obtaining information about all possible correlation of interactions between LEV with epileptic activity during wakefulness and sleep and epilepsy associated sleep disorders; 2 . The relatively small number of subjects.

In 2006 Cicolin et al. published the results of a study on the effect of LEV on nocturnal sleep and daytime vigilance in volunteers only. ${ }^{14}$ The data on the study design and results are presented in Table 1. Disadvantages of this study: 1 . The participation of only healthy subjects excludes obtaining information about all possible interactions between LEV and epileptic activity during wakefulness and sleep and epilepsy associated sleep disorders; 2 . The relatively small number of subjects.

In 2007, Yilmaz published the results of a study evaluating the effects of LEV on motor activity, naps and SE. ${ }^{22}$ The data on the study design and results are presented in Table 1. This is the first study to use actigraphic nap analytical methods comparing LEV-treated patients with a control group. The increased nap episodes were clustered in the morning (from 9 to $11 \mathrm{am}$ ) and in the evening (from 9 to $11 \mathrm{pm}$ ), which was considered as related to the times of LEV administration. Disadvantages of this study are: 1 . The lack of satisfactory information about sleep architecture using solely actimetric analyses instead of a full night PSG; 2 . The participation of only healthy subjects excludes obtaining information about all possible correlation of LEV with epileptic activity during wakefulness and sleep and epilepsy associated sleep disorders. 3. The questionable clinical significance of the increased number of nap episodes and the total nap duration, the last could be clarified using MSLT.

In 2007, Cho et al. published the results of a study focused on evaluation of the effects of LEV on subjective sleep quality and sleep structure in patients with focal epilepsy. ${ }^{23}$ The data on the study design and results are presented in Table 1. The reduction in WASO in the LEV 
Effects of Levetiracetam on Sleep

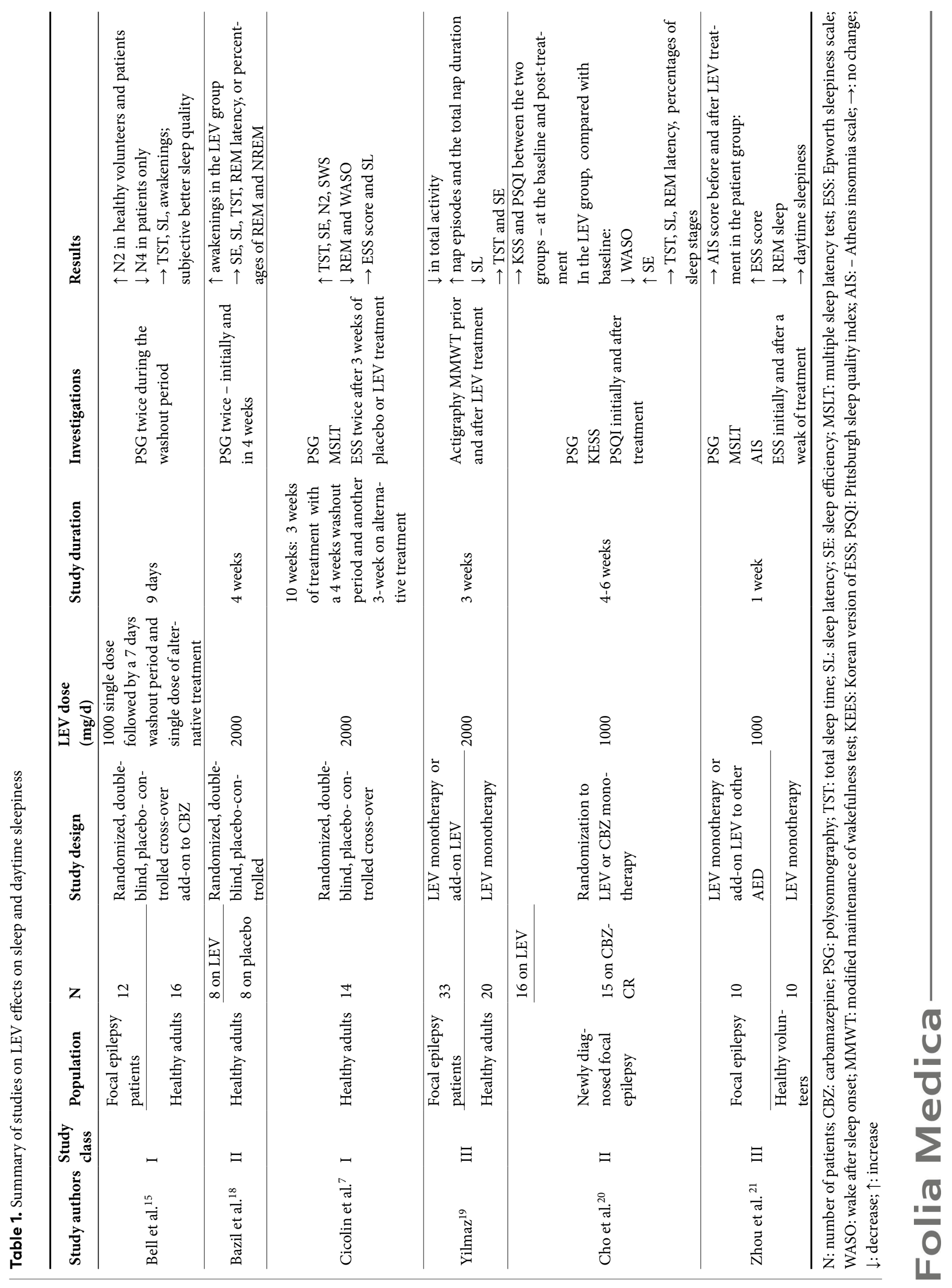


group was accompanied by an increase of SE, although the percentage of NREM and REM sleep remained unchanged. The CBZ-CR group did not share the same beneficial effect on sleep found in the LEV group. The authors presumed that LEV may increase sleep efficiency. Disadvantages of this study are: 1 . The relatively low therapeutic doses; 2 . The usage of two different AEDs makes it difficult to distinguish their effect on the sleep architecture through improved epilepsy control from their direct effect on improved epileptic activity and seizure control.

In 2012, Zhou et al. published the results of a study investigating the acute effects of LEV treatment on nocturnal sleep and daytime sleepiness in adult patients with focal epilepsy (some patients were on LEV add-on therapy) compared with healthy volunteers. ${ }^{24}$ The data on the study design and results are presented in Table 1. Disadvantages of this study are: 1 . The relatively small number of subjects; 2. The comparison of results in patients with epilepsy and healthy volunteers could not provide information about underlying epilepsy effects on sleep; 3 . The relatively short duration of observation.

A summary of all studies' disadvantages is presented in Table 2.

Table 2. Summary of studies' disadvantages

\begin{tabular}{|c|c|c|c|c|c|c|}
\hline $\begin{array}{l}\text { Study disad- } \\
\text { vantages }\end{array}$ & 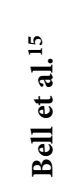 & $\frac{\infty}{\stackrel{\infty}{\pi}}$ & 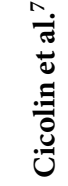 & 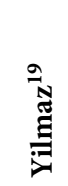 & 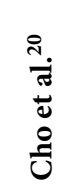 & 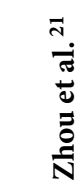 \\
\hline $\begin{array}{l}\text { 1. Single/low } \\
\text { dose of LEV }\end{array}$ & + & & & & + & \\
\hline $\begin{array}{l}\text { 2. LEV add on } \\
\text { therapy/com- } \\
\text { parison with } \\
\text { CBZ }\end{array}$ & + & & & & + & \\
\hline $\begin{array}{l}\text { 3. Compari- } \\
\text { son between } \\
\text { patients and } \\
\text { volunteers }\end{array}$ & + & & & & + & + \\
\hline $\begin{array}{l}\text { 4. Volunteers } \\
\text { only }\end{array}$ & & + & + & + & & \\
\hline $\begin{array}{l}\text { 5. Small num- } \\
\text { ber of subjects }\end{array}$ & & + & + & & & + \\
\hline $\begin{array}{l}6 . \text { Usage of } \\
\text { actimeter } \\
\text { instead of PSG } \\
\text { and MSLT }\end{array}$ & & & & + & & \\
\hline $\begin{array}{l}\text { 7. Short } \\
\text { duration of } \\
\text { observation }\end{array}$ & + & & & & & + \\
\hline
\end{tabular}

LEV: levetiracetam; CBZ: carbamazepine; PSG: polysomnography; MSLT: multiple sleep latency test.

\section{DISCUSSION}

As epilepsy and seizures affect sleep architecture, the effects observed after treatment initiation may be due to improved seizure control rather than a direct effect of AEDs. On the other hand, the observations of volunteers are inconsistent because of eliminating the impact of epilepsy and underlying associated sleep disorders and epileptic activity. Given the small sample size in most of these studies, it was not possible to assume that the obtained data were reliable and could be applied for the epilepsy population. Studies that compared only outcomes in patients with epilepsy with those of healthy controls rather than with the baseline or placebo were also unreliable to determining the true effect of LEV independent of effects of epilepsy. Findings on LEV effects were inconsistent because of differences among studies, including variations in study populations, drug dose, duration of treatment, failure to control seizures, different evaluation modalities and concomitant AED therapy. Due to the above mentioned limitations, it is impossible to reproduce the findings.

\section{CONSLUSIONS}

The negative effect of sleep disturbances on seizure control necessitates thorough knowledge about the sleep profile of AEDs. Therefore future prospective studies on subjective and objective effects of LEV on sleep architecture and daytime sleepiness are needed to better understand its impact on sleep in order to improve epilepsy patients' quality of life, seizure control and sleep disturbances.

\section{REFERENCES}

1. Carskadon MA, Dement WC. Normal human sleep: an overview. In: Kryger MH, Roth T, Dement WC, editors. Principles and practice of sleep medicine. 2nd ed. Philadelphia, PA: Saunders; 1994:16-26.

2. Jain SV, Glauser TA. Effects of epilepsy treatments on sleep architecture and daytime sleepiness: An evidence-based review of objective sleep metrics. Epilepsia 2014; 55:26-37.

3. Iber C, American Academy of Sleep Medicine. The AASM manual for the scoring of sleep and associated events: rules, terminology and technical specifications. Westchester, IL: American Academy of Sleep Medicine; 2007.

4. Wang G, Grone B, Colas D, et al. Synaptic plasticity in sleep: learning, homeostasis and disease. Trends Neurosci 2011; 34:452-63.

5. de Weerd A, de Haas S, Otte A, et al. Subjective sleep disturbance in patients with partial epilepsy: a questionnaire-based study on prevalence and impact on quality of life. Epilepsia 2004;45:1397-404.

6. Bazil CW. Epilepsy and sleep disturbance. Epilepsy Behavior 2003; 4(2):S39-45.

7. Bazil CW. Sleep epilepsy. Seminars in Neurology 2002; 22:321-7.

8. Mendez M, Radtke RA. Interactions between sleep and epilepsy. J Clin Neurophysiol 2001; 18:106-27.

9. Legros B, Bazil CW. Effects of antiepileptic drugs on sleep architec- 
ture: a pilot study. Sleep Med 2003; 4:51-5.

10. Bazil CW, Castro LHM, Walczak TS. Reduction of rapid eye movement sleep by diurnal and nocturnal seizures in temporal lobe epilepsy. Arch Neurol 2000;57:363-8.

11. Alanis-Guevara I, Pena E, Corona T, et al. Sleep disturbances, socioeconomic status, and seizure control as main predictors of quality of life in epilepsy. Epilepsy Behavior 2005; 7:481-5.

12. Foldvary-Schaefer N, Grigg-Damberger M. Sleep and epilepsy. Seminars in Neurology 2009; 29:419-28.

13. Piperidou C, Karlovasitou A, Triantafyllou N, et al. Influence of sleep disturbance on quality of life of patients with epilepsy. Seizure 2008; 17:588-94.

14. Cicolin A, Magliola U, Giordano A, et al. Effects of levetiracetam on nocturnal sleep and daytime vigilance in healthy volunteers. Epilepsia 2006; 47:82-5.

15. Placidi F, Scalise A, Marciani MG, et al. Effect of antiepileptic drugs on sleep. Clin Neurophysiol 2000; 111(suppl 2):S115-9.

16. Ayala-Guerrero F, Mexicano G, Gonzalez V, et al. Effect of oxcarbazepine on sleep architecture. Epilepsy Behavior 2009; 15:287-90.

17. Klitgaard H. Levetiracetam: the preclinical profile of a new class of antiepileptic drugs? Epilepsia. 2001;42 Suppl 4:13-8.
18. Lynch BA, Lambeng N, Nocka K, Kensel-Hammes P, Bajjalieh SM, Matagne A, Fuks B. The synaptic vesicle protein SV2A is the binding site for the antiepileptic drug levetiracetam. Proc Natl Acad Sci U S A. 2004 Jun 29;101(26):9861-6.

19. Viteva IE. Modern drug therapy of epilepsy. 1st ed. Plovdiv: Kableshkov; 2020.

20. Bell C, Vanderlinden H, Hiersemenzel R, et al. The effects of levetiracetam on objective and subjective sleep parameters in healthy volunteers and patients with partial epilepsy. J Sleep Res 2002; 11:255-63.

21. Bazil CW, Battista J, Basner RC. Effects of levetiracetam on sleep in normal volunteers. Epilepsy Behavior 2005; 7:539-42.

22. Yilmaz H. Comparison of motor activity and sleep in patients with complex partial seizures on levetiracetam treatment and a group of healthy subjects. Behav Neurol 2007; 18:165-70.

23. Cho YW, Kim DH, Motamedi GK. The effect of levetiracetam monotherapy on subjective sleep quality and objective sleep parameters in patients with epilepsy: compared with the effect of cabamazepine-CR monotherapy. Seizure 2011; 20:336-9.

24. Zhou JY, Tang XD, Huang LL, et al. The acute effects of levetiracetam on nocturnal sleep and daytime sleepiness in patients with partial epilepsy. J Clin Neurosci 2012; 19:956-60. 


\title{
Влияние леветирацетама на архитектуру сна и дневную сонливость
}

\author{
Орлина Чанева \\ Кафедра неврологии, Медищинский университет - Пловдив, Пловдив, Болгария
}

Адрес для корреспонденции: Орлина Чанева, Кафедра неврологии, Медицинский университет - Пловдив, бул. „Васил Априлов“ № 15А, 4002 Пловдив, Болгария; E-mail: orlina_chaneva@abv.bg; Тел:. +359 883340068

Дата получения: 25 августа 2020 Дата приемки: 11 марта 2021 Дата публикации: 31 октября 2021

Образец цитирования: Chaneva O. Effects of levetiracetam on sleep architecture and daytime sleepiness. Folia Med (Plovdiv) 2021;63(5):631-6. doi: 10.3897/folmed.63.e57985.

\section{Резюме}

Сон - это обратимое поведенческое состояние, в котором сенсорная отстранённость от окружающей среды и отсутствие реакции на неё необходимы для нейропластичности и консолидации памяти. Нарушения сна часто встречаются у больных эпилепсией. Основными причинами нарушений сна являются сопутствующие нарушения сна, последствия судорог и эпилептической активности, а также действие противоэпилептических препаратов. Сон и эпилепсия имеют взаимные эффекты: с одной стороны, электрическая активность мозга во время сна является сильным модулятором эпилептической активности, а с другой - эпилептическая активность во время сна может нарушить структуру сна. Наиболее частые побочные эффекты противосудорожных средств включают изменения в архитектуре сна и вариации степени дневной сонливости. Их влияние на сон и дневную сонливость различается, и часто бывает трудно определить, является ли улучшение контроля над приступами и эпилептической активностью прямым результатом противосудорожных препаратов или связано с улучшением качества сна. Леветирацетам - это противосудорожное средство нового поколения, используемое для лечения как локальной (фокальной) эпилепсии, так и генерализованной эпилепсии. Его удовлетворительная безопасность и переносимость оправдывают его широкое использование в клинической практике и требуют более глубоких знаний о его влиянии на качество сна. Есть несколько исследований, посвящённых его влиянию на структуру сна и дневную сонливость. Представлен краткий обзор исследований по теме. Основными недостатками исследований являются: небольшая выборка, сравнение результатов, полученных среди здоровых добровольцев с пациентами с эпилепсией, короткое наблюдение, вариации доз, разные методы оценки и сопутствующая терапия противоэпилептическими препаратами. Необходимы будущие проспективные исследования субъективного и объективного воздействия леветирацетама на архитектуру сна и дневную сонливость, чтобы лучше понять его влияние на сон с целью улучшения качества жизни пациентов с эпилепсией, контроля припадков и нарушений сна.

\section{Ключевые слова}

дневная сонливость, эпилепсия, леветирацетам, архитектура сна 